\title{
Role of surface chemical signals in egg cannibalism and intraguild predation in ladybirds (Coleoptera: Coccinellidae)
}

\author{
J.-L. Hemptinne', G. Lognay ${ }^{2}$, C. Gauthier ${ }^{2}$ and A. F. G. Dixon ${ }^{3}$ \\ ${ }^{1}$ Ecole Nationale de Formation Agronomique, BP 87, F-31326 Castanet-Tolosan, France \\ ${ }^{2}$ Faculté Universitaire des Sciences Agronomiques, Passage des Déportés, 2, B-5030 Gembloux, Belgium \\ ${ }^{3}$ School of Biological Sciences, University of East Anglia, Norwich NR4 7TJ, UK
}

Summary. The eggs of some ladybirds are known to be toxic to intraguild ladybird predators. However, this defence is of little value if the eggs are killed before their toxicity becomes apparent. The results presented in this paper indicate that chemicals on the surface of the eggs of two species of ladybirds signal the relative risk of cannibalism and intraguild predation. In Adalia bipunctata and Coccinella septempunctata, $87 \%$ of the chemicals are alkanes. Each species of ladybird is less reluctant to eat their own eggs than those of the other species. This asymmetry is to be expected because there is a greater risk to ladybirds from intraguild predation than cannibalism. Similar alkanes to those on the surface of the eggs of $A$. bipunctata are present in tracks left by larvae and on the elytra of the adults of this species. Those in the larval tracks deter females from ovipositing in patches of prey already being attacked by their larvae and those on the elytra are used in mate recognition. That different context dependent messages could be signalled by similar chemicals is an example of semiochemical parsimony.

Key words. Alkanes - intraguild predation - egg cannibalism - Adalia bipunctata - Coccinella septempunctata

\section{Introduction}

Both in terms of intraguild predation and cannibalism the eating of eggs by ladybirds would appear to be advantageous in that it both supplies a source of food and removes potential competitors (Polis 1981). Although the disadvantages of consuming one's kin has been considered (Osawa 1992; Joseph et al. 1999) those associated with eating toxic eggs of other species, although well described (Agarwala \& Dixon 1992), has been ignored. The larvae of Adalia bipunctata (L.) and Coccinella septempunctata L., which regularly co-occur in the field, are reluctant to eat conspecific eggs painted with water extracts of whole eggs of the other species,

Correspondence to: J.-L. Hemptinne, e-mail: jean-louis. hemptinne@educagri.fr and larvae of $C$. septempunctata are more likely to develop more slowly and/or die after eating a few eggs of $A$. bipunctata than vice versa (Agarwala \& Dixon 1992; Hemptinne et al. 2000). However, the water extract of crushed whole eggs is likely to contain the species specific alkaloids that are known to be present in ladybird eggs (Pasteels et al. 1973). Some of these alkaloids are known to be toxic to vertebrates (Frazer \& Rothschild 1960; Marples et al. 1989) and therefore it does not seem unreasonable to assume they are responsible for the toxicity of ladybird eggs. Starving adults of Menochilus sexmaculatus (F.) and Coccinella transversalis (F.) both consume their own eggs more readily than those of the other species, and $C$. transversalis is more reluctant to eat the eggs of $M$. sexmaculatus than vice versa (Agarwala et al. 1998).

Although the eggs of ladybirds are defended chemically such defence would be of little value if the eggs are killed before their toxicity becomes apparent. Therefore, it would be advantageous for both predator and egg if the toxicity of the latter could be flagged in some way. Close observation revealed that on encountering eggs larvae palpated their surface and then often quickly withdrew leaving the eggs intact. That is, whatever was responsible for a larva's change in behaviour appeared to be on the surface of the eggs, and therefore unlikely to be the species specific alkaloid.

Each species of ladybird prefers a particular habitat or range of habitats, and shows varying degrees of overlap in its preference(s) with other species (Honek 1985; Majerus 1994; Nedved 1999). Those species whose eggs and larvae regularly co-occur are the most likely to be well defended against one another. $C$. septempunctata shows a marked preference for herbaceous plants and although $A$. bipunctata is not so restricted its immature stages nevertheless frequently co-occur with those of C. septempunctata (Smee 1922; Banks 1955, 1956; Smith 1966; Radwan \& Lövei 1982, 1983; Hemptinne \& Naisse 1988; Hemptinne 1989; Barczak et al. 1996; Trouvé et al. 1996). As indicated above these two species are protected against predation by one another.

The following study was undertaken in order to test the hypothesis that substances on the surface of ladybird eggs afford them some protection from cannibal- 
ism and intraguild predation, and to identify these substance(s) in two species of ladybirds.

\section{Material and methods}

\section{Ladybird culture}

Two-spot ladybirds, A. bipunctata, were reared at $15 \pm 1{ }^{\circ} \mathrm{C}$ and a photoperiod of $16 \mathrm{~h}$ light and $8 \mathrm{~h}$ darkness. Groups of approximately twenty males and twenty females were kept in 5 litre plastic boxes, which also contained a piece of corrugated filter paper to increase the surface area. Every other day the ladybirds were fed an excess of the pea aphid, Acyrthosiphon pisum (Harris). On that occasion, a piece of stem of broad bean, Vicia faba L., was put in each of the rearing boxes to provide a source of humidity and of food for the aphids. Once a week the ladybirds were transferred to clean containers to stimulate egg laying.

The same rearing procedure were followed for the seven-spot ladybird, C. septempunctata, except for the temperature, which was maintained at $25^{\circ} \mathrm{C}$ to encourage egg production.

The corrugated filter paper was changed every day and any egg batches were removed from the paper by cutting round them with fine scissors. Each piece of paper with a batch of eggs was incubated in $175 \mathrm{~cm}^{3}$ boxes at $15+1^{\circ} \mathrm{C}$ and a photoperiod of $16 \mathrm{~h}$ light and $8 \mathrm{~h}$ darkness. After hatching the larvae were kept 15 to a box in order to reduce the risk of cannibalism. From the beginning of the third instar the larvae were isolated in 5-cm diameter Petri dishes lined with filter paper. Throughout their development the larvae were fed an excess of pea aphids.

\section{Intraguild predation and cannibalism of eggs by fourth instar larvae}

Two days after moulting to the fourth instar, a larva of A. bipunctata was transferred to a 9-cm diameter Petri dish lined with filter paper and kept for $3 \mathrm{~h}$ without aphids. Then each larva was gently placed in the centre of a 9-cm diameter Petri dish lined with filter paper and containing a batch of a minimum 10 conspecific eggs located close to the rim of the dish. The larva was observed under a binocular microscope. On its first encounter with the eggs, it was noted whether it immediately backed away from the eggs or not. If it did not avoid the eggs, how many were crushed or eaten was recorded. There were 20 replicates, which each lasted for $15 \mathrm{~min}$ from the time of first encountering the batch of eggs. Twenty fourth instar larvae of $A$. bipunctata were then similarly offered a batch of seven-spot eggs. The same experiment was repeated but with larvae that were previously kept for 24 hours without food.

In the next experiment fourth instar larvae of C. septempunctata, which were starved for 3 or 24 hours, were offered, as above, conspecific or $A$. bipunctata eggs.

The numbers of larvae that avoided or ate the eggs were analysed using a standard $\chi^{2}$ test. The numbers of encounters with the eggs in the following 15 -min were analysed by means of a Mann-Whitney's test. Egg consumption in the different treatments was compared by a Kruskal-Wallis test (Zar 1996).

\section{Are ladybird eggs protected against cannibalism and intraguild predation?}

Following the above procedure, a fourth instar larva of $\mathrm{A}$. bipunctata was placed in a 9-cm diameter Petri dish containing either a batch of conspecific eggs, a batch of conspecific eggs washed in $\mathrm{n}$-hexane or a batch of conspecific eggs previously washed in n-hexane and then painted with the aid of an Hamilton ${ }^{\circledR}$ micro-syringe with an hexane extract obtained from a corresponding number of eggs. There were 21 replicates of each treatment. Eggs to be washed were first removed from the filter paper on which they were laid by means of a fine paintbrush after wetting the filter paper with de-ionised water, then immersed in groups of 150 in 0.5 $\mathrm{ml}$ of $\mathrm{n}$-hexane for $2 \mathrm{~min}$. For the third treatment, the hexane extract was carefully painted on to hexane washed eggs under a binocular microscope to avoid losses. In this way, the extract was delivered in quantities small enough that it did not spread onto the surrounding substrate. The washed and painted eggs were dried for $30 \mathrm{~min}$ in a fume cupboard on a piece of filter paper before being presented to the larvae. Hexane was chosen as a solvent because a preliminary study indicated that it did not penetrate into eggs during the $2 \mathrm{~min}$ extraction period, and only removes chemicals present on the surface of the eggs (Chan 1995), and it does not affect the hatching success (Guo \& Dixon, unpublished). This experiment was then repeated using fourth instar larvae of $A$. bipunctata presented with similarly treated eggs of $C$. septempunctata. The proportions of larvae eating eggs were compared by means of a $\chi^{2}$ test and the numbers of eggs eaten were analysed by means of a Kruskall-Wallis test.

Fourth instar larvae of $C$. septempunctata were also offered similarly treated eggs of $A$. bipunctata. The numbers of replicates varied from 20 to 16 depending on the treatment.

\section{Chemical analysis of the $n$-hexane extract}

Eggs of A. bipunctata were collected daily from the ladybird culture, detached from the filter paper on which they were laid as described before and 50 of them placed in a small conical flask. They were washed for $2 \mathrm{~min}$ in $500 \mu \mathrm{l}$ of $\mathrm{n}$-hexane. This extract was evaporated under a gentle stream of nitrogen and the dry residue dissolved in $100 \mathrm{ml}$ of $\mathrm{n}$-hexane. The extracts from 22 groups of 50 eggs were pooled prior to Gas Chromatography-Mass Spectrometry (GC-MS). The same procedure was followed to obtain an extract from 433 eggs of C. septempunctata.

The GC-MS was done on a Hewlett-Packard HP 5989 Mass Spectrometer coupled to a HP 5890 Serie II gas chromatograph equipped with a HP-5 (crosslinked $5 \%$ phenyl-methylpolysiloxane) column $(30 \mathrm{~m} \times 0.25 \mathrm{~mm}$ I.D.; film thickness $0.25 \mu \mathrm{m})$. The operating conditions were fixed as follows: split-splitless injector at $275^{\circ} \mathrm{C}$; carrier gas: helium at $0.9 \mathrm{ml} \mathrm{min}{ }^{-1}$; temperature programme: from $50^{\circ} \mathrm{C}$ to $140^{\circ} \mathrm{C}$ at $20^{\circ} \mathrm{C} \mathrm{min}{ }^{-1}$ then from $140^{\circ} \mathrm{C}$ to $290^{\circ} \mathrm{C}$ at $5^{\circ} \mathrm{C}$ $\min ^{-1}$ with a final hold of $30 \mathrm{~min}$ at $290^{\circ} \mathrm{C}$. The mass spectra were recorded in the electron impact mode at $70 \mathrm{eV}$ (Source Temperature: $200^{\circ} \mathrm{C}$, scanned mass range: 35 to $600 \mathrm{amu}$ ).

The peaks were identified by their retention data and their characteristic fragmentation patterns. The identification of straightchain hydrocarbons and free fatty acids were confirmed by co-injections of pure references. Their mass spectra were also compared with those of the NBS 75K.L and WILEY 138.L computer MS libraries. The structural assignments of internally methyl-substituted hydrocarbons were performed on the basis of the prominent mass ions $\mathrm{C}_{\mathrm{n}} \mathrm{H}_{2 \mathrm{n}+1}$ and $\mathrm{C}_{\mathrm{n}} \mathrm{H}_{2 \mathrm{n}}$ (McCarthy et al. 1968) formed by the $\alpha$-cleavage at the branch position(s). The 2-methylalkanes were fragmented to give a characteristic strong M-43 ion (loss of an isopropyl group) and a less intense M-15 peak (loss of a methyl group). For the 3-methylalkanes, a characteristic M-29 peak (loss of an ethyl group) together with a smaller M-57 fragment (loss of a secondary butyl group) were the diagnostic ions.

To measure the quantity of each of the alkanes present in the extracts, eggs of $A$. bipunctata were separated from filter paper as above. A group of 50 eggs was washed for $2 \mathrm{~min}$ in a solution of $400 \mu \mathrm{l}$ of $\mathrm{n}$-hexane plus $100 \mu \mathrm{l}$ of a solution of $12.05 \mathrm{mg} \mathrm{n}$-dodecane $/ 20 \mathrm{ml}$ of hexane, which was the internal standard. This extract was evaporated under a gentle stream of nitrogen, the dry residue was dissolved in $100 \mathrm{ml}$ of $\mathrm{n}$-hexane and then analysed by gas chromatography on a Carlo Erba 5060 Mega fitted with a cold on-column injector and a FID detector maintained at $295^{\circ} \mathrm{C}$. A fused silica OPTIMA 1 column $(30 \mathrm{~m} \times 0.32 \mathrm{~mm}$ I.D.; film thickness $0.35 \mu \mathrm{m}$ ) from Macherey-Nagel was used for the analysis. The temperature programme was identical to that of the GC-MS analytical procedure. For diagnostic purposes, the relative retention times of the different peaks were calculated with n-tricosane as a reference and compared to the GC-MS chromatographic data and to the retention times of n-alkane homologs injected under the same conditions. This was repeated 9 times. Then three extracts of five batches of 34 to 47 eggs of C. septempunctata were treated similarly. 


\section{Results}

Intraguild predation and cannibalism of eggs by fourth instar larvae

After starving for 3 hours fourth instar larvae of $A$. bipunctata were reluctant to eat the eggs of their own species and did not eat those of C. septempunctata (Fig. 1). On first encountering two-spot eggs, 13 out of 20 larvae backed away; 11 out of 20 larvae behaved similarly on encountering seven-spot eggs. These two proportions do not differ significantly $\left(\chi^{2}=0.417,1\right.$ d.f., $P>0.05)$. During the course of the experiment, the two-spot larvae on average encountered batches of their own eggs twice as frequently as batches of seven-spot eggs (Mann-Whitney's $U=305.5 ; P=0.004$ ). Two-spot larvae appeared to be less active in the presence of seven-spot than two-spot eggs. After 24 hours starvation the proportion of two-spot larvae eating their own eggs increased $\left(\chi^{2}=6.144,1\right.$ d.f., $\left.P=0.013\right)$ but they still did not eat $C$. septempunctata eggs (Fig. 1A). That is, the larvae of $A$. bipunctata ate more conspecific eggs after a long than a short period of starvation (Fig. 1B: Mann-Whitney's $U=271 ; P=0.015$ ).

The period of starvation, similarly, affected the consumption of eggs of $A$. bipunctata by larvae of $C$. septempunctata. The longer period of starvation resulted in a greater proportion of larvae eating $\left(\chi^{2}=\right.$ $13.745,1$ d.f., $P=0.000$ ) and a greater number of eggs

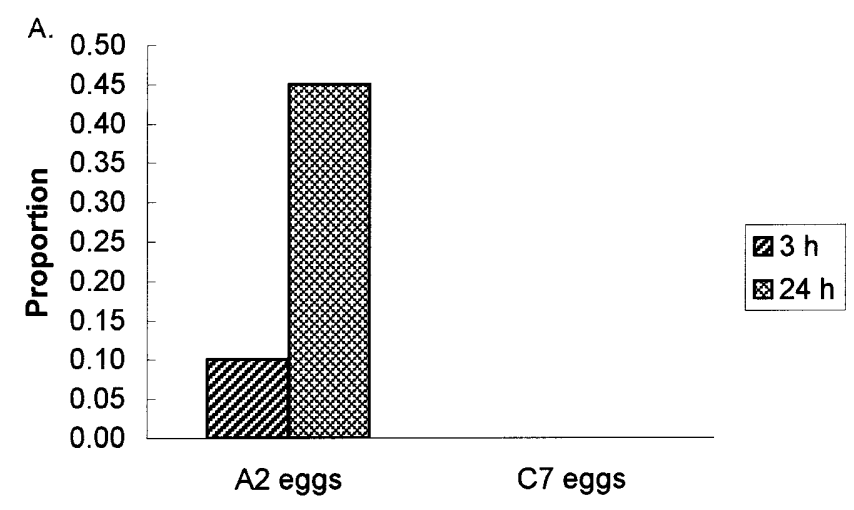

B.

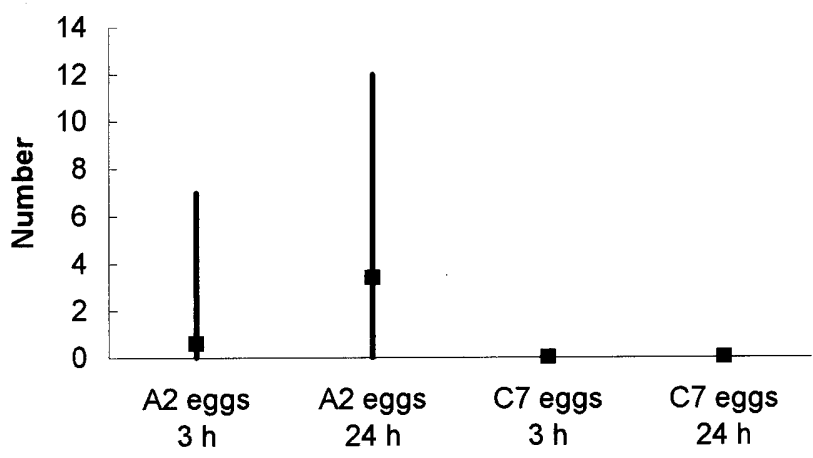

Fig. 1 The proportion of fourth instar larvae of Adalia bipunctata starved for 3 or 24 hours that ate eggs (A) and the maximum, average and minimum numbers of eggs they ate (B) when offered either a batch of Coccinella septempunctata eggs or a batch of conspecific eggs
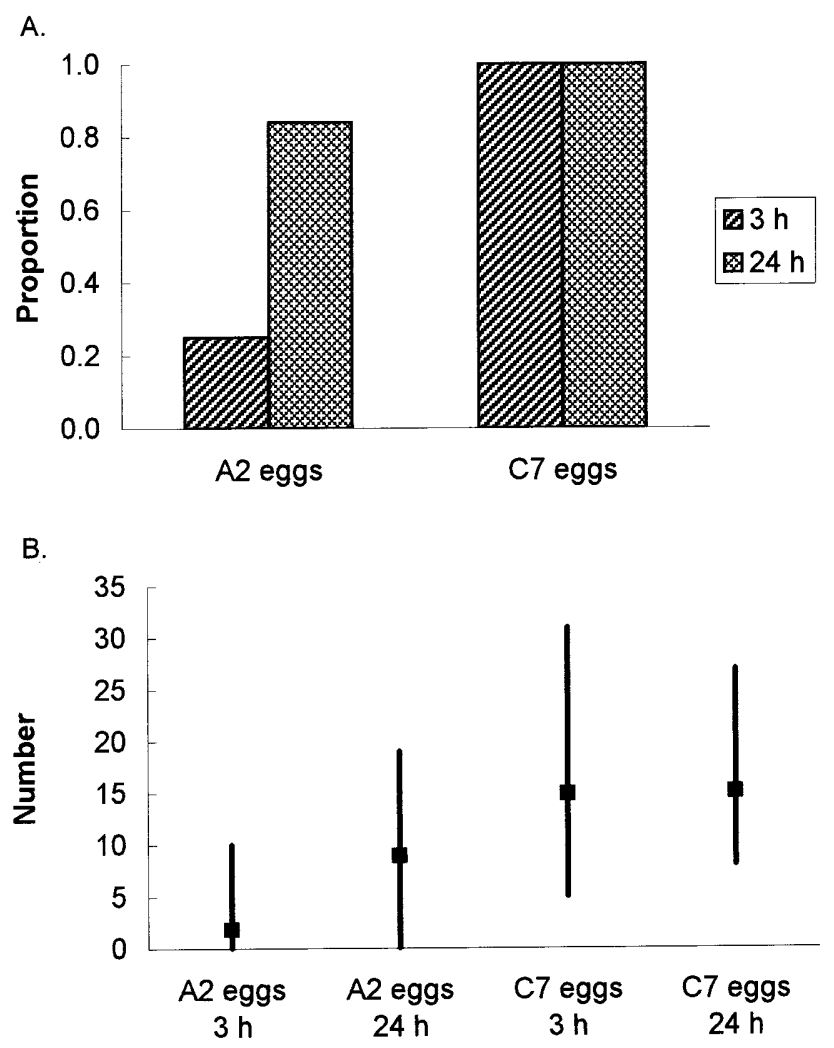

Fig. 2 The proportion of fourth instar larvae of Coccinella septempunctata starved for 3 or 24 hours (A) and the maximum, average and minimum numbers of eggs they ate (B) when offered either a batch of Adalia bipunctata or a batch of conspecific eggs

eaten (Mann-Whitney's $U=61 ; P=0.000$ ). In contrast it had almost no affect on the consumption of conspecific eggs (Fig. 2).

That is, hungry two-spot larvae refused to eat seven-spot eggs and were reluctant to eat their own species eggs, whereas seven-spot larvae readily ate their own species eggs and avoided eating two-spot eggs unless very hungry.

\section{Are ladybird eggs protected against cannibalism and intraguild predation?}

The fourth instar larvae of $A$. bipunctata ate numerically and proportionally significantly more washed than unwashed, or painted conspecific eggs (Table 1). They were extremely reluctant to eat eggs of $C$. septempunctata. Although the differences between the three treatments were not significant, the proportion of larvae eating at least one seven-spot egg increased when the eggs were washed in hexane.

Similarly, fourth instar larvae of C. septempunctata were reluctant to eat two-spot eggs. Few of them consumed unwashed eggs or painted eggs. However, nearly all the larvae ate washed eggs. Significantly more washed eggs were eaten than unwashed or painted eggs (Table 2).

That is, A. bipunctata eggs are protected against both cannibalism and intraguild predation by $C$. sep- 


\begin{tabular}{|c|c|c|c|c|c|c|}
\hline & \multicolumn{6}{|c|}{ Eggs offered } \\
\hline & \multicolumn{3}{|l|}{ Two-spot } & \multicolumn{3}{|l|}{ Seven-spot } \\
\hline & unwashed & washed & painted & unwashed & washed & painted \\
\hline $\mathrm{n}_{\mathrm{t}}$ & 21 & 21 & 21 & 20 & 19 & 10 \\
\hline $\mathrm{n}_{\mathrm{e}}$ & 7 & $\begin{array}{l}18 \\
15.37(P<0.001)\end{array}$ & 7 & 2 & $6.61(P>0.05)$ & 1 \\
\hline Min & 0 & 0 & 0 & 0 & 0 & 0 \\
\hline Max & 10 & 10 & 10 & 1 & 4 & 2 \\
\hline $\begin{array}{l}\text { Mean } \\
\text { KW test }\end{array}$ & 2.7 & $\begin{array}{l}7.9 \\
18.07(P=0.00)\end{array}$ & 2.5 & 0.1 & $\begin{array}{l}0.6 \\
3.63(P=0.16)\end{array}$ & 0.2 \\
\hline
\end{tabular}

Table 1 The number of fourth instar larvae of Adalia bipunctata that ate eggs, and the numbers of eggs eaten, when offered either two-spot or seven-spot eggs that were unwashed, washed in hexane or washed in hexane and painted with extract

$\mathrm{n}_{\mathrm{t}}=$ total number of larvae; $\mathrm{n}_{\mathrm{e}}=$ number of larvae eating eggs; $\mathrm{KW}$ test $=$ Kruskall-Wallis test

tempunctata larvae by one or several n-hexane soluble substances on the surface of their eggs. Eggs of $C$. septempunctata are strongly protected against intraguild predation by $A$. bipunctata but not against cannibalism.

\section{Chemical analysis of the n-hexane extract of the} surface covering of eggs

$87 \%$ of the molecules in the hexane extract of the surface of the eggs of $A$. bipunctata are either linear hydrocarbons [heneicosane $(\mathrm{C} 21)$, docosane $(\mathrm{C} 22)$ and tricosane $(\mathrm{C} 23)$ ] or branched hydrocarbons [7-methyltricosane (7Me-C23) and 9-methyl-tricosane (9Me-tricosane)]. 7Me-C23 and 9Me-C23 made up a fairly large percentage of the hydrocarbon profile $(29 \%$ and $50 \%$ respectively); C22 made up only a small percentage $(2 \%)$ (Table 3$)$.

The hexane extract of the surface of the eggs of $C$. septempunctata is more complex and less concentrated. It contains hydrocarbons with an even number of carbon atoms [docosane (C22), tetracosane (C24), hexacosane (C26) and octacosane (C28)] and an odd number of carbon atoms [tricosane (C23), pentacosane (C25), heptacosane (C27) and nonacosane (C29)]. The latter are dominant and among them $\mathrm{C} 27$ makes up $40 \%$ of the total (Table 3). Although the chromatographic profile from the GC-MS analysis is similar to that obtained from gas chromatography in displaying ten major peaks, it only reveals the hydrocarbons with odd numbers of carbon atoms. The concentration of

Table 2 The number of fourth instar larvae of Coccinella septempunctata that ate eggs, and the numbers of eggs eaten, when they were offered two-spot eggs that were unwashed, washed in hexane or washed in hexane and painted with extract

\begin{tabular}{llll}
\hline & \multicolumn{2}{l}{ Two-spot eggs } \\
\cline { 2 - 4 } & unwashed & washed & painted \\
\hline $\mathrm{n}_{\mathrm{t}}$ & 20 & 20 & 16 \\
$\mathrm{n}_{\mathrm{e}}$ & 5 & 19 & 8 \\
$\chi^{2}$ test & 0 & $20.47(P<0.001)$ & 0 \\
Min & 10 & 0 & 10 \\
Max & 1.8 & 11.8 & 1.9 \\
Mean & & $24.63(P=0.000)$ & \\
$\quad \mathrm{KW}$ test & & &
\end{tabular}

$\mathrm{n}_{\mathrm{t}}=$ total number of larvae; $\mathrm{n}_{\mathrm{e}}=$ number of larvae eating eggs; $\mathrm{KW}$ test $=$ Kruskall-Wallis test hydrocarbons with even numbers of carbons was probably insufficient to be detected. Peak number 10 corresponds to a mixture of $\mathrm{C} 28$ branched hydrocarbons. In addition to hydrocarbons, there are other compounds not yet identified. On average, there was less hydrocarbon material on the surface of $C$. septempunctata eggs $(1.10 \mu \mathrm{g} / 50 \mathrm{eggs})$ than of $A$. bipunctata eggs $(4.20 \mu \mathrm{g} / 50$ eggs).

\section{Discussion}

There is an increasing body of evidence that all stages of ladybirds contain species specific alkaloids (Pasteels et al. 1973; Daloze et al. 1995; King \& Meinwald 1996) and that these substances are toxic to other ladybirds (Agarwala \& Dixon 1992; Hemptinne et al. 2000.). Accepting that they are toxic, then there are advantages in each developmental stage being able to flag its toxicity. The experiments reported here indicate that the hexane soluble molecules on the surface of the eggs flag this information. The hexane extract consists mainly of alkanes $(87 \%)$.

The mechanism by which insect predators recognize their prey has been poorly studied. Although adult ladybirds have well developed eyes they nevertheless recognize conspecifics during mating by their surface

Table 3 Concentration, in $\mu \mathrm{g} / 50$ eggs, of the hydrocarbons in the n-hexane extract of the surface covering of the eggs of Adalia bipunctata and Coccinella septempunctata

\begin{tabular}{llllll}
\hline Hydrocarbons & \multicolumn{2}{l}{ A. bipunctata } & & \multicolumn{2}{c}{ C. septempunctata } \\
\cline { 2 - 3 } \cline { 5 - 6 } & Mean & SD & & Mean & SD \\
\hline C21 & 0.5 & 0.1 & & \\
C22 & 0.1 & 0.0 & & 0.04 & 0.01 \\
C23 & 0.3 & 0.1 & & 0.13 & 0.07 \\
7Me-C23 & 1.2 & 0.2 & & \\
9Me-C23 & 2.1 & 0.5 & & 0.11 & 0.10 \\
C24 & & & 0.17 & 0.07 \\
C25 & & & 0.05 & 0.02 \\
C26 & & & 0.44 & 0.21 \\
C27 & & & 0.04 & 0.00 \\
C28 & & & 0.12 & 0.07 \\
C29 & 4.2 & & 1.10 & \\
Total & & & &
\end{tabular}


chemistry (Hemptinne et al. 1998). Ladybird larvae have poorly developed eyes and do not appear to use visual stimuli in prey recognition (Dixon 2000). Therefore, it is likely that larvae also use surface chemistry in prey recognition. Although the surface chemistry of different stages of an insect varies (Carlson et al. 1999; Nielsen et al. 1999; Wagner et al. 1998), nevertheless, it is likely to be more similar within than between species and thus could function as a species specific signal (Blows \& Allan 1998; Lahav et al. 1999; Liu et al. 1999; Nielsen et al. 1999). If this is the case then the reluctance to eat conspecific eggs might indicate that well fed larvae generally avoid attacking individuals of the same species as there is a risk of the attacker becoming the victim in case of a size handicap. If starving, however, cannibalism becomes more advantageous.

Intraguild predation involves an additional risk, as not only might the attacker become the victim it may also be poisoned by eating its victim (Hemptinne et al. 2000). Thus generally, one would expect ladybirds to show greater reluctance to attack and eat other species eggs than their own eggs. This is supported by the results presented here. In addition one would expect this asymmetry to apply also to the interactions between larvae and, larvae and pupae: be more cautious if not conspecific!

The alkanes on the surface of the eggs of two-spot ladybirds are similar to those in the tracks left by their larvae, which are thought to deter females from ovipositing in patches of prey already attacked by their larvae (Doumbia et al. 1998; Hemptinne et al., in prep.), and on the surface of adult elytra, which males appear to use in mate recognition (Hemptinne et al. 1998). That is, these alkanes probably signal a context specific message. In the context of predation, they signal relative risk; in mating, species recognition and in oviposition, the presence of conspecific larvae. This is probably an example of what Blum (1996) refers to as semiochemical parsimony.

\section{Acknowledgements}

This work was supported by grants awarded by the Fonds National de la Recherche scientifique, Le Commissariat général aux Relations extérieures de la Communauté française de Belgique and The British Council, and The Royal Society to J.-L.H. and A.F.G.D. C.G. benefited from a Pic Erasmus grant of the E U. The authors are greatly indebted to Benoît Adam and Alexandra Magro for helping with the experiments.

\section{References}

Agarwala BK, Dixon AFG (1992) Laboratory study of cannibalism and interspecific predation in ladybirds. Ecological Entomology 17:303-309

Agarwala BK, Bhattacharya S, Bardhanroy P (1998) Who eats whose eggs? Intra- versus interspecific interactions in starving ladybird beetles predaceous on aphids. Ethology Ecology \& Evolution 10:361-368
Banks CJ (1955) An ecological study of Coccinellidae (Col.) associated with Aphis fabae Scop. on Vicia faba. Bulletin of Entomological Research 46:561-587

Banks CJ (1956) Observations on the behaviour and mortality in Coccinellidae before dispersal from the egg shells. Proceedings of the Royal Entomological Society of London 31:56-60

Barczak T, Kaczorowski G, Burmistrzak M (1996) Coccinellid beetles (Coccinellidae, Col.) associated with populations of Aphis fabae Scop. - complex (Aphididae, Hom.) on spindle bush. Preliminary results. $\mathrm{Pp} 15-22$ in Narkiewicz-Jodko J, Cichocka E, Nawrocka B, Goszcynski W, (eds) Aphids and Other Homopterous Insects, vol 5, Skierniewice: Polish Academy of Sciences Vth Division - Agricultural and Forest Sciences

Blows MW, Allan RA (1998) Level of mate recognition within and between two Drosophila species and their hybrids. American Naturalist 152:826-837

Blum MS (1996) Semiochemical parsimony in the Arthropoda. Annual Review of Entomology 41:353-374

Carlson DA, Geden CJ, Bernier UR (1999) Identification of pupal exuviae of Nasonia vitripennis and Muscidifurax raptorellus parasitoids using cuticular hydrocarbons. Biological Control 15:97106

Chan F-Y (1995) Etude des alcaloïdes de Adalia bipunctata (L.) en relation avec le comportement de l'insecte. MSc thesis, Faculté universitaire des Sciences agronomiques, Gembloux (Belgium), $71 \mathrm{p}$.

Daloze D, Braeckman J-C, Pasteels J-M (1995) Ladybird defence alkaloids: structural, chemotaxonomic and biosynthetic aspects (Col.: Coccinellidae). Chemoecology 5/6:173-183

Dixon AFG (2000) Insect Predator-Prey Dynamics. Ladybird Beetles and Biological Control. Cambridge University Press, Cambridge (UK), $272 \mathrm{pp}$

Doumbia M, Hemptinne J-L, Dixon AFG (1998) Assessment of patch quality by ladybirds: role of larval tracks. Oecologia 113:197-202

Frazer JFD, Rothschild M (1960) Defence mechanisms in warningly coloured moths and other insects. Proceedings of the 11th International Congress of Entomology, Wiena, Verhandlungen B 3:249-256

Hemptinne J-L (1989) Ecophysiologie d'Adalia bipunctata (Coleoptera, Coccinellidae). PhD Thesis, Université Libre de Bruxelles, Belgium, $156 \mathrm{pp}$

Hemptinne J-L, Naisse J (1988) Life cycle strategy of Adalia bipunctata (L.) (Col., Coccinellidae) in a temperate country. Pp 71-77 in Niemczyk E, Dixon AFG (eds) Ecology and Effectiveness of Aphidophaga, SPB Academic Publishing, The Hague

Hemptinne J-L, Lognay G, Dixon AFG (1998) Mate recognition in the two-spot ladybird beetle, Adalia bipunctata: role of chemical and behavioural cues. Journal of Insect Physiology 44:11631171

Hemptinne J-L, Dixon AFG, Gauthier C. (2000) Nutritive cost of intraguild predation in ladybirds (Coleoptera: Coccinellidae). European Journal of Entomology, in press

Honek A (1985) Habitat preferences of aphidophagous coccinellids (Coleoptera). Entomophaga 30:253-264

Joseph SB, Snyder WE, Moore AJ (1999) Cannibalizing Harmonia axyridis (Coleoptera: Coccinellidae) larvae use endogenous cues to avoid eating relatives. Journal of Evolutionary Biology 12:792-797

King AG, Meinwald J (1996) Review of the defensive chemistry of coccinellids. Chemical Review 96:1105-1122

Lahav S, Soroker V, Hefetz A, Vander Meer RK (1999) Direct behavioral evidence for hydrocarbons as ant recognition discriminators. Naturwissenschaften 86:246-249

Liu ZB, Yamane S, Wang QC, Yamamoto H (1999) Nestmate recognition and temporal modulation in the patterns of cuticular hydrocarbons in natural colonies of Japanese carpenter ant Camponotus japonicus Mayr (Hymenoptera:Formicidae). Journal of Ethology 34:179-188

McCarthy ED, Han J, Calvin M (1968) Hydrogen atom transfer in mass spectrometric fragmentation patterns of saturated aliphatic hydrocarbons. Annals of Chemistry 40:1475-1480

Majerus MEN (1994) Ladybirds. The New Naturalist. Harper Collins Publishers, London, $367 \mathrm{pp}$ 
Marples NM, Brakefield PM, Cowie RJ (1989) Differences between the 7-spot and 2-spot ladybird beetles (Coccinellidae) in their toxic effects on a bird predator. Ecological Entomology 14:7984

Nedved O (1999) Host complexes of predaceous ladybeetles (Col., Coccinellidae). Journal of Applied Entomology 123:73-76

Nielsen J, Boomsma JJ, Oldham NJ, Petersen HC, Morgan ED (1999) Colony-level and season-specific variation in cuticular hydrocarbon profiles of individual workers in the ant Formica truncorum. Insectes sociaux 46:58-65

Osawa N (1992) Sibling cannibalism in the ladybird beetle Harmonia axyridis: fitness consequences for mother and offspring. Researches on Population Ecology 34:45-55

Pasteels JM, Deroe C, Tursch B, Braekman JC, Daloze D, Hootele C (1973) Distribution et activités des alcaloides defensifs des Coccinellidae. Journal of Insect Physiology 19:1771-1784

Polis GA (1981) The evolution and dynamics of intraspecific predation. Annual Review of Ecology and Systematics 12:225-251

Radwan Z, Lövei GL (1982) Distribution and bionomics of ladybird beetles (Col., Coccinellidae) living in an apple orchard near

Received 25 February 2000; accepted 22 May 2000.
Budapest, Hungary. Zeitschrift für angewandte Entomologie 96:169-175

Radwan Z, Lövei GL (1983) Structure and seasonal dynamics of larval, pupal, and adult coccinellid (Col., Coccinellidae) assemblages in Hungary. Zeitschrift für angewandte Entomologie 96:396-408

Smee C (1922) British ladybird beetles. Their control of aphids. The Fruit Grower 53:675-676

Smith BD (1966) Effects of parasites and predators on a natural population of the aphid Acyrthosiphon spartii (Koch) on broom (Sarothamnus scoparius L.). Journal of Animal Ecology 35:255267

Trouvé C, Ledée S, Brun J, Ferran A (1996) Lutte biologique contre les pucerons du Houblon. Phytoma 486:41-44

Wagner D, Brown MJF, Broun P, Cuevas W, Moses LE, Chao DL, Gordon DM (1998) Task-related differences in the cuticular hydrocarbon composition of harvester ant, Pogonomyrmex barbatus. Journal of Chemical Ecology 24:2021-2037

Zar JH (1996) Biostatistical Analysis. Prentice-Hall International Inc., Upper Saddle River, N.J., 662 p 